\title{
Optimasi Produksi Usahatani Karet di Kecamatan Tapung Hulu Kabupaten Kampar
}

\author{
Elinur*, Heriyanto, dan Joko Saputra \\ Universitas Islam Riau \\ * elinurdjaimi@agr.uir.ac.id
}

\begin{abstract}
Abstrak. Perkebunan Karet rakyat di Kecamatan Tapung Hulu pada umum belum mencapai tingkat produktivtas yang tinggi. Penelitian ini bertujuan untuk menganalisis faktor dominan yang mempengaruhi produksi karet, tingkat efisiensi produksi dari aspek efisiensi teknis, alokatif dan ekonomi dan produksi optimum usahatani karet. Penelitian ini dilakukan dengan menggunakan metode survei yang berlokasi di Kecamatan Tapung Hulu Kabupaten Kampar. Data yang digunakan adalah data primer yang diperoleh dengan menggunakan metode wawancara. Sampel diambil dengan metode simple random sampling dengan 45 petani karet. Analisis data menggunakan statistik infrensia dengan regresi linear berganda dan metode Data Enveloment Analysis (DEA). Hasil Penelitian menunjukkan bahwa faktor dominan yang mempengaruhi produksi karet adalah tenaga kerja, pupuk TSP dan herbisida. Ketiga faktor produksi tersebut signifikan dan bepengaruh positif terhadap produksi karet dengan elastisitas produksi inlastis. Hasil analisis DEA menunjukkan bahwa pada umumnya petani karet inefisiensi secara teknis, alokatif dan ekonomi. Banyak petani yang inefisiensi secara teknis dan alokatif serta ekonomi disebabkan petani belum menggunakan faktor produksi yang efisien. Faktor produksi yang digunakan petani lebih rendah dari yang direkomendasikan. Dengan demikian perlu penyuluhan kepada petani karet tentang penggunaan input yang efisien.
\end{abstract}

Kata Kunci: optimasi produksi, efisiensi dan Data Enveloment Analysis (DEA)

\section{PENDAHULUAN}

Karet merupakan tanaman perkebunan yang sudah biasa dibudidayakan oleh masyarakat dan sebagai sumber pendapatan rumahtangga. Sebagai sumber pendapatan tanaman karet harus diusahakan oleh petani sebaik mungkin agar menghasilkan produksi yang optimum dan keuntungan yang maksimum. Untuk mencapai hal tersebut petani dapat menggunakan faktor produksi (bibit, tenaga kerja, pupuk, dan pestisda) yang efisien.

Kecamatan Tapung Hulu merupakan salah satu kecamatan penghasil karet di Kabupaten Kampar Provinsi Riau. Perkebunan karet di Kecamatan Tapung Hulu merupakan perkebunan rakyat. Perkembangan luas lahan karet tahun 2015 seluas 6170 hektar dan 2287 hektar tahun 2016. Produksi karet yang dihasilkan masing sebesar 3882 ton dan 1130 ton pada tahun 2015 dan 2016 dengan tingkat produkstivtas masing 0,63 dan 0,49 pada tahun 2015 dan 2016. Hal ini menunjukkan luas lahan dan produksi serta produkstivitas karet rakyat di Kecamatan Tapung Hulu mengalami penurunan. Menurunnya luas lahan dan produksi karet akan menyebabkan rendahnya produkstivitas karet. Rendahnya tingkat produktivitas karet rakyat tersebut diduga disebabkan kurangnya pemeliharaan tanaman karet oleh petani, sebagian besar karet petani masih banyak gulma di sekelilingnya. Selain itu, penggunaan faktor yang belum efisien secaa teknis, alokatif dan ekonomi, seperti penggunaan bibit semaian yang tidak terseleksi, tidak menggunakan pupuk sesuai dengan yang rekomendasikan. Dengan demikian faktor- faktor apa saja yang mempengaruhi produksi karet petani karet, dan seberapa besar tingkat efisiensi produksi petani karet dari aspek efisiensi teknis, alokaif dan ekonomi dan bagaimana solusi yang dilakukan petani untuk mencapai tingkat efisiensi produksi?

Berdasarkan hal tersebut maka penelitian secara umum bertujuan untuk menganalisis tingkat efisensi produksi petani karet sehingga dapat menggambarkan tingkat efisiensi produksi pada setiap petani karet. Secara spesifik penelitian ini bertujuan, yaitu: (1) mengalisis faktor dominan yang mempengaruhi produksi karet, (2) menganalisis tingkat efisiensi produksi dari aspek teknis, alokatif dan ekonomi pada setiap petani sampel dan tingkat produksi optimum petani karet mencapai efisien secara teknis, alokatif dan ekonomi.

To cite this article: Elinur, Heriyanto, dan J. Saputra. 2019. Optimasi Produksi Usahatani Karet di Kecamatan Tapung Hulu Kabupaten Kampar Unri Conference Series: Agriculture and Food Security 1: 15-25. https://doi.org/10.31258/unricsagr.1a3 


\section{KAJIAN PUSTAKA}

Menurut Agroforestri dan Kehutanan (2013) tanaman karet merupakan komoditi perkebunan yag sangat penting dalam industri otomotif. Perkebunan karet di Indonesia 85 persen dikuasai oleh perkebunan rakyat yang diusahakan dalam skala kecil. Perkebunan karet sebagian besar terdapat di Sumatera dan Kalimantan, dengan sentra produksi tersbar di Sumatera Selatan (688 ribu hektar) Sumatera Utara (465 ribu hektar), Sumatra Utara (465 ribu hektar), Jambi (444 ribu hektar), Riau (390 ribu hektar), Kalimantan Barat (388 ribu hektar) dan Sulawasi Selatan (19 ribu hektar).

Perkebunan karet rakyat biasanya dikelola dengan teknik budidaya sederhana berupa pemupukan sesuai kemampuan petani. Karet ditanam bersama dengan pohon-pohon lain seperti pohon buahbuahan (contohnya durian, petai, jengkol, dan duku) maupun pohon penghasil kayu (contohnya merantidan tembesu) yang sengaja ditanam atau tumbuh sendiri secara alami. Sebaliknya, perkebunan besar dikelola dengan teknik budidaya yang lebih maju dan intensif dalam bentuk perkebunan monokultur, yaitu hanya tanaman karet saja, untuk memaksimalkan hasil kebun.

Para petani karet di Indonesia saat ini masih banyakyang menggunakan bibit karet cabutan, anakan liar,atau hasil semaian biji dari pohon karet alam yang dibudidayakan sebelumnya. Meskipun demikian, bibit karet unggul sebenarnya sudah dikenal luas oleh petani. Bibit karet unggul dihasilkan dengan teknik okulasi antara batang atas dengan batang bawah yang tumbuh dari biji-biji karet pilihan.

Dalam menghasilkan tingkat produksi karet yang tinggi maka tanaman perlu diberi pupuk. Menurut Anwar (2001) program pemupukan dilakukan secara berkelanjutan pada tanaman karet dengan dosis yang seimbang. Pemupukan dilakukan dua kali dalam setahun. Seminggu sebelum pemupukan, gawangan lebih dahulu digaru dan piringan tanaman dibersihkan.Pemberian SP-36 biasanya dilakukan dua minggu lebih dahulu dari Urea dan $\mathrm{KCl}$. Program dan dosis pemupukan tanaman karet secara umum dapat dilihat pada Tabel 1.

Tabel 1. Rekomendasi Umum Pemupukan Tanaman Karet

\begin{tabular}{ccccc}
\hline $\begin{array}{c}\text { Umur } \\
\text { Tanaman }\end{array}$ & $\begin{array}{c}\text { Urea } \\
(\mathrm{g} / \mathrm{ph} / \mathrm{th})\end{array}$ & $\begin{array}{c}\mathrm{SP} \mathrm{36} \\
(\mathrm{g} / \mathrm{ph} / \mathrm{th})\end{array}$ & $\begin{array}{c}\mathrm{KCl} \\
(\mathrm{g} / \mathrm{ph} / \mathrm{th})\end{array}$ & $\begin{array}{c}\text { Frekuensi } \\
\text { pemupukan }\end{array}$ \\
\hline $6-15$ & 350 & 260 & 300 & $2 \mathrm{kali} / \mathrm{th}$ \\
$16-25$ & 300 & 190 & 250 & $2 \mathrm{kali} / \mathrm{th}$ \\
>22 sampai 2 tahun sebelum peremajaan & 200 & - & 150 & $2 \mathrm{kali} / \mathrm{th}$ \\
\hline
\end{tabular}

Setelah tanaman karet berumur 5 tahun, tanaman sudah dapat disadap untuk diambil getahnya sebagai produksi karet. Menurut Anwar (2001), produksi lateks dari tanaman karet disamping ditentukan oleh keadaan tanah dan pertumbuhan tanaman, klon unggul, juga dipengaruhi oleh teknik dan manajemen penyadapan. Apabila ketiga kriteria tersebut dapat terpenuhi, maka diharapkan tanaman karet pada umur 5 6 tahun telah memenuhi kriteria matang sadap. Kriteria matang sadap antara lain apabila keliling lilit batang pada ketinggian $130 \mathrm{~cm}$ dari tanah telah mencapai minimum $45 \mathrm{~cm}$. Jika $60 \%$ dari populasi tanaman telah memenuhi kriteria tersebut, maka areal pertanaman sudah siap dipanen. Produksi lateks per satuan luas dalam kurun waktu tertentu dipengaruhi oleh beberapa faktor antara lain klon karet yang digunakan, kesesuaian lahan dan agroklimatologi, pemeliharaan tanaman belum menghasilkan, sistem dan manajemen sadap, dan lainnya. Karena produksi kebun karet adalah lateks, maka estimasi produksi per hektar per tahun dikonversikan ke dalam satuan getah karet basah yang disajikan pada Tabel 2.

Tabel 2. Produksi Karet Kering dan Produksi Lateks

\begin{tabular}{|c|c|c|c|}
\hline \multicolumn{2}{|c|}{ Tahun } & \multicolumn{2}{|c|}{ Produksi } \\
\hline Umur & Sadap & KKK (ton/ha) & Latek (liter/ha) \\
\hline 6 & 1 & 500 & 2.000 \\
\hline 7 & 2 & 1.150 & 4.600 \\
\hline 8 & 3 & 1.400 & 5.600 \\
\hline 9 & 4 & 1.600 & 6.400 \\
\hline 10 & 5 & 1.750 & 7.000 \\
\hline 11 & 6 & 1.850 & 7.400 \\
\hline 12 & 7 & 2.200 & 8.800 \\
\hline 13 & 8 & 2.300 & 9.200 \\
\hline 14 & 9 & 2.350 & 9.400 \\
\hline
\end{tabular}




\begin{tabular}{|c|c|c|c|}
\hline \multicolumn{2}{|c|}{ Tahun } & \multicolumn{2}{|c|}{ Produksi } \\
\hline Umur & Sadap & KKK (ton/ha) & Latek (liter/ha) \\
\hline 15 & 10 & 2.300 & 9.200 \\
\hline 16 & 11 & 2.150 & 8.600 \\
\hline 17 & 12 & 2.100 & 8.400 \\
\hline 18 & 13 & 2.000 & 8.000 \\
\hline 19 & 14 & 1.900 & 7.600 \\
\hline 20 & 15 & 1.800 & 7.200 \\
\hline 21 & 16 & 1.650 & 6.600 \\
\hline 22 & 17 & 1.550 & 6.200 \\
\hline 23 & 18 & 1.450 & 5.800 \\
\hline 24 & 19 & 1.400 & 5.600 \\
\hline 25 & 20 & 1.350 & 5.400 \\
\hline 26 & 21 & 1.200 & 4.800 \\
\hline 27 & 22 & 1.000 & 4.600 \\
\hline 28 & 23 & 1.150 & 4.000 \\
\hline 29 & 24 & 850 & 3.400 \\
\hline 30 & 25 & 800 & 3.200 \\
\hline
\end{tabular}

Panjaitan (2014), melakukan penelitian tentang efesiensi produksi jagung. Metode penetuan sampel yang di gunakan adalah simple random sampling dengan jumlah sampel 82 petani. Pengujian hipotesis menggunakan metode (1) metode deskriptif yaitu menjelaskan bagaimana produksi jagung di daerah penelitian, (2) metode analisis fungsi Coob-Douglas serta alat bantu SPSS dan program Data Envelopment Analysis (DEA) untuk memperoleh nilai efesiensi, (3) metode analisis penerimaan dan pendapatan, dan (4) metode analisis R/C dan BEP.

Dari hasil penelitian di peroleh (1) nilai efesiensi harga untuk setiap input yaitu bibit 0,141 ; pupuk 0,033 ; herbisida 0,022 dan tenaga kerja 0,014. Dari nilai tersebut dapat dikatakan tidak efesiensi $(<1)$ dalam penggunaan input, perlu pengurangan jumlah untuk setiap input yang di gunakan. Secara teknis, pengunaan input produksi tidak efisien dengan nilai efisiensi $0,94125<1$ (2) jumlah penerimaan usahatani jagung di daerah penelitian adalah RP 2.709.525.000,00 dengan jumlah biaya produksi 1.513.197.460,00 sehingga di peroleh total pendapatan bersih usahatani jagung di daerah penlitian sebesar Rp. 1.196.327.540, 00 dan pendapatan petani per ha sebesar Rp. 9. 650.915,94 (3) nilai R/C yang di peroleh 1,79 > 1 serta nilai BEP volume $540.722 \mathrm{~kg}$ dengan BEP harga Rp. 1. 572, 97 maka usahatani jagung di daerah penelitian layak di ushakan dan menguntukan.

Risandewi (2013), Analisis Efisiensi Produksi Kopi Robusta Di Kabupaten Temanggung (Studi Kasus Di Kecamatan Candiroto). Penelitian ini bertujuan untuk mengetahui tingkat efisiensi produksi usaha perkebunan kopi rakyat, menganalisis faktor-faktor produksi yang mempengaruhi tingkat produksi kopi rakyat dan merumuskan rekomendasi apa yang dapat dilakukan untuk meningkatkan efisiensi produksi kopi robusta di Kecamatan Candiroto. Metode penelitian yang akan digunakan adalah penelitian survey. Analisis data penelitian menggunakan analisis statistik non parametrik dengan menggunakan alat analisis Data Envelopment Analysis (DEA) dan statistik parametrik dengan menggunakan regresi linier berganda. Teknik penarikan sampel dalam penelitian ini menggunakan proposional quota sampling. Sampel ditentukan sebanyak 50 orang petani yang tersebar secara proporsional di sepuluh desa di Kecamatan Candiroto.

Tingkat efisiensi produksi rata-rata kopi robusta di Kecamatan Candiroto masih belum efisien yaitu 73,24\%. Desa Mento merupakan desa dengan tingkat efisiensi produksi yang paling tinggi dan Desa Sidoharjo dan Muntung yang paling rendah. Faktor-faktor yang mempengaruhi secara signifikan terhadap tingkat produksi kopi robusta di Kecamatan Candiroto adalah luas lahan, jumlah tenaga kerja, jumlah tanaman,penggunaan pupuk, dan umur tanaman. Hanya variabel umur tanaman kopi yang bertanda negatif terhadap tingkat produksi kopi robusta. Cara meningkatkan efisiensi produksi kopi robusta untuk masingmasing petani di Kecamatan Candiroto rata-rata dengan cara mengurangi jumlah tenaga kerja yang tidak diperlukan, peremajaan umur kopi robusta,mengurangi jumlah pupuk agar tidak berlebihan sehingga mengurangi kesuburan tanah, intensifikasi lahan.

Utami (2013) melakukan penelitian tentang efisiensi produksi pada pabrik engolahan kelapa sawit Di Pt. Gersido Minang Plantation Kecamatan Lingkung Aur Kabupaten Pasaman Barat. Analisis data yang digunakan adalah analisis fungsi produksi regresi berganda dan analisis optimalisasi skala usaha. PT GMP 
telah mengaplikasikan teknologi modern dalam seluruh proses produksinya, dengan menggunakan sejumlah mesin pengolah yang tersusun dalam kerangka sistem produksi yang telah mapan, mulai dari penimbangan sampai pada proses pemurnian dan penjernihan minyak kasar.

Hasil analisa regresi faktor-faktor produksi dengan tingkat signifikansi 0,05, diperoleh bahwa walau secara Simultan (uji F) seluruh faktor produksi secara bersama-sama berpengaruh nyata terhadap hasil produksi CPO (Crude Palm Oil), ternyata secara parsial (uji t) hanya variabel tandan buah segar, bahan kimia, dan tenaga kerja yang berpengaruh nyata. Sehingga, faktor produksi Bahan Bakar dan Air, yang tidak berpengaruh nyata, dikeluarkan dari model fungsi produksi.

Hasil analisa skala usaha dari model yang kedua ini menunjukkan bahwa tingkat produksi pengolahan kelapa sawit di PT.Gersindo Minang Plantation saat ini berada pada "skala usaha yang sedang meningkat atau increasing return to scale", sehingga selanjutnya dapat diperkirakan tingkat penggunaan faktor produksi yang optimumnya. Perhitungan tingkat optimum dilakukan pada faktor produksi TBS karena nilai rasio NPM/BKM yang mendekati satu dan koefisien variabel yang paling signifikan, sehingga diperoleh tingkat produksi pada penggunaan TBS sebanyak 36.075 ton/perbulan. Untuk itu, perusahaan disarankan untuk dapat meningkatkan penggunaan faktor produksi TBS sampai mendekati kapasitas pabrik sebesar 37.085 ton TBS perbulan.

Wulandari, dkk (2014) mengalisis produksi dan efisiensi produksi kelapa (Cocos nucifera. Linn) perkebunan rakyat di Kabupaten Indragiri Hilir. Penelitian ini menggunakan metode survei yang dilakukan dengan fungsi produksi Cocos nucifera, dengan metode analisis adalah regresi berganda. Sampel dalam penelitian ini sebanyak 40 responden dengan metode Multy Stage Sampling.

Hasil penelitian menunjukan faktor dominan yang signifikan mempengaruhi produksi kelapa adalah jumlah tanaman menghasilkan dan pengunaan pupuk. Sedangkan, tenaga kerja dan umur tanaman tidak mempengaruhi produksi kelapa. Efisiensi teknis nilai MPP umur tanaman adalah 0,32, artinya setiap pertambahan umur tanaman sebesar 1 tahun akan meningkatkan jumlah produksi sebesar 0,32 ataun1 butir/ha/tahun. Pada efisiensi Alokatif adalah nilai VMP/Px untuk penggunaan pupuk adalah $0,03<1$, artinya bahwa alokasi penggunaan pupuk tidak efisien secara harga. Untuk mencapai kondisi efisien perlu dilakukan pengurangan penggunaan pupuk. Dan Efisiensi Ekonomi untuk penggunaan pupuk adalah 0,01, artinya penggunan pupuk sudah mencapai kondisi efisien secara ekonomi.

Marjelita dkk (2015) melakukan penelitian tentang efisiensi produksi petani padi sawah peserta Operasi Pangan Riau Makmur (OPRM) di Kabupaten Kampar. Dalam penelitian tersebut efisensi produksi yang dihitung dari aspek teknis, alokatif dan ekonomis. Analisis efisiensi menggunakan metode Data Envelopment Analysis (DEA). Hasil penelitian ini menunjukkan bahwa produksi padi sawah program OPRM secara nyata dan positif dipengaruhi oleh penggunaan luas lahan, pupuk urea, SP36, KCL, pupuk organik cair, penggunaan tenaga kerja, dummy kesesuaian lahan, pengalaman berusahatani, dan pendidikan petani. Rata-rata petani padi sawah peserta OPRM di daerah penelitian belum efisien secara teknis, alokatif dan ekonomis. Hal ini karena petani program OPRM diberikan bantuan modal berupa pupuk dan benih, namun tidak memeberikannya sesuai anjuran yang ditetapkan. Perbandingan tingkat efisiensi teknis, alokatif dan ekonomis petani peserta program OPRM dan bukan OPRM hanya sedikit. Semestinya petani program OPRM memiliki nilai efisiensi yang jauh lebih tinggi dari bukan program OPRM. Hal ini terjadi tidak berpengaruh signifikannya perbadaan antara program dan non program, sesuai kondisi dilapangan bahwa petani program OPRM belum melukukan kegiatan usahatani sesuai yang diharapkan pemerintah.

\section{METODE}

Metode penelitian adalah metode survei yang berlokasi di Kecamatan Tapung Hulu Kabupaten Kampar. Penelitian ini di laksanakan selama 6 bulan dari bulan Agustus 2017 sampai dengan bulan Januari 2018. Data penelitian ini adalah data primer. Metode pegumpulan data adalah metode wawancara kepada petani karet. Metode pegambilan sampel dengan random sampling yang diambil dari Desa Kasikan, Bukit Kemuning, Kusau Makmur, Sukai Ramai, Sinama Nenek, dan Desa Tanah Datar. Jumlah sampel sebanyak 48 petani karet. Analisis data menggunakan analisis statistik dengan fungsi produksi Cobb Douglas untuk menjawab faktor-faktor yang mempengaruhi produksi karet. Model fungsi produksi Cocos nucifera karet dalam penelitian ini, yaitu:

$\mathrm{Y}=\beta 0 \mathrm{X} 1 \beta 1 . \mathrm{X} 2 \beta 2 . \mathrm{X} 3 \beta 3 . \mathrm{X} 4 \beta 4 . \mathrm{X} 5 \beta 5 \mathrm{X} 6 \beta 6 \mathrm{X} 7 \beta 7 . \mathrm{eu}$.

dimana:

Y : Produksi $(\mathrm{Kg})$ 
X1 : Tanaman Menghasilkan (Jumlah pohon/Ha)

$\mathrm{X} 2$ : Tenaga Kerja (HKP/Ha)

$\mathrm{X} 3$ : Urea $(\mathrm{Kg} / \mathrm{Luas}$ garapan)

$\mathrm{X} 4$ : Dolomit (Kg/Luas garapan)

$\mathrm{X} 5$ : KCL (Kg/Luas garapan)

$\mathrm{X} 6$ : Pupuk TSP $(\mathrm{Kg} / \mathrm{Luas}$ garapan)

$\mathrm{X} 7$ : Pestisida (Liter/Luas garapan)

Efisiensi produki dianalisis adalah efisiesi teknis, alokatif (harga) dan efisiensi ekonomi. Perhitungan efisiensi produksi tersebut menggunakan pendekatan output. Dalam artian meningkatan produksi yang optimum dengan menggunakan faktor produksi yang efisien. Analisis Efisiensi teknis, alokatif (harga) dan efisiensi ekonomi diperoleh dengan menggunakan program Data Envelopment Analysis (DEA) versi 2.1.

\section{HASIL DAN PEMBAHASAN}

\section{Faktor Dominan yang Mempengaruhi Produksi Karet}

Faktor-faktor yang berpengaruh terhadap produksi karet di Kecamatan Tapung Hulu Kabupaten Kampar adalah luas lahan yang diproksi dari jumlah tanaman menghasilkan, tenaga kerja, pupuk urea, pupuk dolomit, pupuk $\mathrm{KCl}$, pupuk TSP, herbisida. Hasil estimasi fungsi produksi karet dapat dilihat pada Tabel 3.

Tabel 3. Hasil Estimasi Fungsi Produksi Karet Rakyat di Kecamatan Tapung Hulu Kabupaten Kampar Tahun 2017

\begin{tabular}{lrrrrr}
\hline \multicolumn{1}{c}{ Variabel } & \multicolumn{1}{c}{$\begin{array}{c}\text { Parameter } \\
\text { Estimasi }\end{array}$} & $\begin{array}{c}\text { Standard } \\
\text { Error }\end{array}$ & \multicolumn{1}{c}{ V Value } & \multicolumn{1}{c}{ Pr $>|t|$} & \multicolumn{1}{c}{$\begin{array}{c}\text { Variance } \\
\text { Inflation }\end{array}$} \\
\hline Intercept & 3,44891 & 1,32946 & 2,59 & 0,0122 & 0 \\
Jumlah tanaman & 0,13646 & 0,21931 & 0,62 & 0,5365 & 1,19495 \\
menghasilkan & 0,57567 & 0,17811 & 3,23 & $0,0021^{*}$ & 1,50856 \\
Tenaga kerja & 0,00120 & 0,00164 & 0,74 & 0,4653 & 1,37543 \\
Pupuk urea & 0,00035562 & 0,00509 & 0,07 & 0,9446 & 1,18270 \\
Dolomid & 0,0008943 & 0,00292 & 0,31 & 0,7609 & 1,45682 \\
Pupuk KCL & 0,75267 & 0,10912 & 6,90 & $<, 0001^{*}$ & 1,14351 \\
Pupuk TSP & 0,79892 & 0,03512 & 22,75 & $<, 0001^{*}$ & 1,34302 \\
Pestisida & & & & & 0,9391 \\
R-Square & & & & & 0,000 \\
Fsig & & & & & \\
Durbin-Watson & & & & &
\end{tabular}

Keterangan: $*=$ Berpengaruh nyata pada taraf $\alpha=5 \%$

Tabel 3 menunjukkan peubah tenaga kerja, pupuk TSP dan pestisida berpengaruh positif dan signifikan terhadap produksi karet pada taraf kepercayaan $5 \%(\alpha=5 \%)$. Sedangkan peubah tanaman menghasilkan, pupuk urea, dolomid dan pupuk KCL tidak signifkan mempengaruhi produksi karet. Tenaga kerja, pupuk TSP dan herbisida berpengaruh positif terhadap produksi bermakna bahwa peningkatan tenaga kerja, pupuk KCL dan pestisida akan meningkatkan produksi karet. Hal ini berarti petani dapat penambahan faktor produksi tersebut agar produksi capaiannya maksimum. Berbeda hal dengan menambah pupuk KCL, penambahan pupuk KCL akan menyebabkan tambahan produksi karet menurun. Diduga bahwa penggunaan pupuk KCL untuk tanaman karet sudah berlebih sehingga tambahan pupuk KCL akan menyebabkan tambahan produksi karet berkurang. Berdasarkan hasil uji F menujukkan nilai F Sig adalah 0,000 (Tabel 5.6). Hal ini bermakna bahwa variabel bebas secara bersama-sama berpengaruh nyata terhadap produksi karet. Hal ini berarti model fungsi produksi karet dapat dikatakan baik secara statistik.

Suatu model dikatakan baik secara statistik juga dapat dilihat dari nilai koefisien determinasi (R2). Hasil penelitian menunjukkan bahwa nilai koefisien determinasi yaitu sebesar 0,939. Hal ini bermakna bahwa variasi peubah independen (jumlah tanaman menghasilkan, tenaga kerja, pupuk urea, dolomit, pupuk KCL, pupuk TSP dan herbsida) mampu menjelaskan variasi peubah produksi karet sebesar 93,9\% dan sisanya sebesar $6,1 \%$ ditentukan oleh variabel lain yang tidak dimasukan dalam model yang diwakilkan oleh peubah error term.

Dari hasil penelitian ini dapat dibuat model fungsi produksi karet di Kecamatan Tapung Hulu. Model produksi karet di Kecamatan Tapung Hulu Kabupaten Kampar adalah:Y = 3,44891 + 0,136X1 + 0,576X2 + 
$0,001 X 3+0,0004 X 4-0,0009 X 5+0,753 X 6+0,799 X 7$. Hasil penelitian ini akan memudahkan petani dalam meningkatkan produksi karet dengan meningkat faktor produksi yang signifikan terhadap produksi karet (tenaga kerja, pupuk TSP dan pestisida). Dengan demikian faktor produksi tersebut dapat diakses oleh petani.

\section{Tenaga Kerja}

Tenaga kerja yang digunakan dalam usahatani karet di Kecamatan Tapung Hulu Kabupaten Kampar keseluruhan berasal dari dalam keluarga tanpa menggunakan tenaga kerja yang berasal luar keluarga. Hasil analisis uji-t diketahui bahwa Thitung 3,23 dengan probabilitas 0,002 , probabilitas dibawah 0,005 . Ini berarti faktor produksi tenaga kerja yang digunakan dalam usahatani karet berpengaruh secara nyata terhadap produksi karet pada taraf kepercayaan $95 \%$.

Nilai parameter dugaan peubah tenaga kerja sebesar 0,576. Nilai tesebut juga menunjukkan nilai elastisitas produksi. Hal ini berarti setiap peningkatan $1 \%$ tenaga kerja yang digunakan untuk berusahatani karet mampu meningkatkan produksi karet sebesar $0,576 \%$. Demikian pula sebaliknya, setiap terjadi pengurangan $1 \%$ tenaga kerja, maka akan menurunkan produksi karet sebesar $0,576 \%$ dengan asumsi variabel lain tetap.

\section{Pupuk TSP}

Pupuk merupakan salah satu faktor produksi yang berpengaruh terhadap produksi. Adapun tujuan pemberian pupuk adalah untuk mengisi kekurangan unsur hara tanaman dalam tanah, sehingga kebutuhan unsur hara tanaman terpenuhi untuk tumbuh subur dan ikuti dengan meningkatnya produksi. Pemberian pupuk yang tepat waktu, tepat dosis dan tepat cara pemberiannya, diharapkan akan dapat meningkatkan produksi petani menggunakan pupuk TSP. Mengacu pertumbuhan akar tanaman menujang agar batang tetap tegak sehingga mengurangi resiko rebahnya tanaman.

Hasil analisis uji-t diketahui bahwa Thitung 6,90 dengan tingkat probabilitas $<, 001$, probabilitas dibawah 0,005. Ini menunjukkan bahwa faktor produksi pupuk TSP yang di gunakan dalam usahatani karet berpengaruh secara nyata terhadap pada produksi karet pada taraf kepercayaan 95\%. Selain itu, pupuk TSP berpengaruh positif tehadap produksi karet. Hal ini berarti peningkatan pupuk TSP akan meningkatkan produksi karet.

Parameter dugaan untuk pupuk TSP sebesar 0,753. Nilai tersebut bermakna setiap peningkatan $1 \%$ pupuk TSP yang digunakan untuk berusahatani karet mampu meningkatkan produksi karet sebesar $0,753 \%$. Demikian pula sebaliknya, setiap terjadi pengurangan $1 \%$ pupuk TSP, maka akan menurunkan produksi karet sebesar $0,752 \%$ dengan asumsi variabel lain tetap.

\section{Pestisida}

Pestisida yang digunakan dalam usahatani karet di Kecamatan Tapung Hulu Kabupaten Kampar meliputi round-up dan gromoxone. Herbisida tersebut diperoleh petani dari toko-toko pertanian yang berada di desa tempat petani tinggal dengan pembelian yang dilakukan secara tunai. Pestisida tersebut digunakan petani untuk membasmi lalang dan rumput yang mengganggu perkembangan tanaman karet.

Hasil analisis uji-t diketahui bahwa Thitung 22,75 dengan tingkat probabilitas <,001, probabilitas dibawah 0,005. Ini mempunyai arti bahwa faktor produksi pestisida yang digunakan dalam usahatani karet berpengaruh secara nyata terhadap pada produksi karet pada taraf kepercayaan 95\%. Selain itu, herbsida berpengaruh positif tehadap produksi karet. Hal ini berarti peningkatan penggunaan herbisida akan meningkatkan produksi karet.

Parameter dugaan untuk pestisida sebesar 0,799 artinya setiap peningkatan $1 \%$ herbisida yang digunakan untuk berusahatani karet mampu meningkatkan produksi karet sebesar $0,799 \%$, demikian pula sebaliknya, setiap terjadi pengurangan $1 \%$ herbisida, maka akan menurunkan produksi karet sebesar $0,799 \%$ dengan asumsi variabel lain tetap, Parameter dugaan pestisida juga menggambarkan elastisitas produksi, sehingga elastisitas produksi herbisida adalah 0,799 .

\section{Efesiensi Produksi Karet}

Efesiensi produksi adalah kemampuan menghasilkan output pada suatu tingkat kualitas tertentu dengan biaya yang lebih rendah. Dalam ilmu ekonomi konsep efisiensi penggunaan faktor produksi dibedakan dalam 3 hal, yaitu efesiensi teknis, efesiensi alokatif (harga), dan efesiensi ekonomis (Coelli et al., 1998).

Metode lain yang dapat digunakan untuk mengukur tingkat efisiensi adalalah metode Data Envelopment Anaysis (DEA). DEA merupakan metode untuk menganalisis efisiensi relatif dari suatu unit pengambilan keputusan (petani) yang bertanggung jawab terhadap penggunaan sejumlah input untuk memperoleh suatu 
output yang ditargetkan. DEA merupakan metode pemograman fraksional yang mencakup banyak output dan input. Efisiensi realatif yang diukur tersebut merupakan pengukuran mengukur suatu Unit Kegiatan Ekonomi (UKE) dibanding dengan UKE lain dalam sampel yang menggunakan jenis input dan output yang sama.

Nilai efisiensi relatif dalam metode DEA berkisar antara 0 dan 1. Dalam metode DEA. Decision Making Unit (DMU) atau Unit Pembuat Keputusan (UPK) atau unit kegiatan ekonomi (UKE) adalah petani sampel. Sebuah Unit Kegiatan Ekonomi (UKE) atau Decission Making Unit (DMU) dikatakan efisien apabila nilai efisiensinya baik teknis, alokatif dan ekonomi (rasio perbandingan antara output terhadap faktor produksinya) bernilai 1 . Sebaliknya, tidak efisien jika bernilai 0 . Nilai efisiensi 0 , artinya DMU/UKE/Petani tersebut melakukan pemborosan penggunaan faktor produksi, dan atau tidak mampu berproduksi pada penggunaan output yang optimal. Sebaliknya nilai efisiensi 1 berarti DMU/UKE/Petani tersebut penggunaan faktor produksi secara optimal, sehingga mampu berproduksi maksimum.

Metode pengukuran nilai efisiensi dalam DEA menggunakan pendekatan Variable Returns to Scale (VRS). Metode DEA VRS mengasumsikan UKE/Petani belum berproduksi pada skala optimum dengan pertimbangan bahwa usahatani karet belum beroperasi pada skala yang optimal karena adanya keterbatasan biaya produksi dalam menggunakan faktor produksi.

\section{Efesiensi Teknis}

Efisien teknis merupakan besaran yang menunjukkan perbandingan antara produksi sebenarnya dengan produksi maksimum, Perhitungan efisiensi dilakukan dengan menghitung Marginal Physical Product (MPP) dari masing-masing factor produksi. MPP adalah perubahan output yang diakibatkan oleh adanya perubahan satu unit input. Proporsi nilai efisiensi teknis petani sampel disajikan pada Gambar 1.

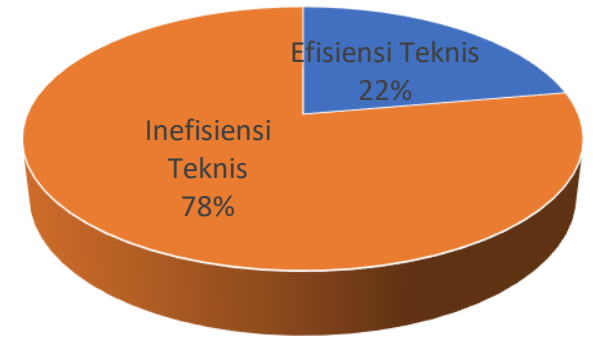

Gambar 1. Proporsi Efisiensi dan Inefisiensi Teknis Petani Karet di Kecamatan Tapung Hulu Tahun 2018

Berdasarkan Gambar 1 dapat dijelas bahwa 22 persen petani karet efisien secara teknis dalam mengelola usahataninya, sisanya 78 persen inefisiensi. Nilai efisiensi teknis petani berkisar antara 0 dan 1 . Nilai efisiensi teknis yang terkecil sebesar 0.69 , yaitu petani sampel ke-40 dan nilai efisiensi teknis petani yang tertinggi sebesar 1 sebanyak 9 petani, yaitu petani sampel ke 5, 9, 12, 21, 22, 24, 35, 36, 37, dan 42. Nilai efisiensi teknis rata-rata petani karet sebesar 0.89 persen. Hal ini bermakna setiap penambahan 1 unit faktorfaktor produksi akan meningkatkan produksi karet sebesar 0.89 persen, cateris paribus.

Perbedaan tingkat efisiensi teknis yang dicapai petani akan mempengaruhi perbedaan penggunaan faktor produksi pada masing-masing petani dengan luasan lahan yang sama. Penggunaan faktor produksi petani karet yang efisien untuk menghasilkan produksi yang optimal dan keuntungan yang maksimal. Disisi lain, petani karet yang tidak efisien (inefisiensi) berarti belum menghasilkan produksi optimal. Agar mencapai tingkat efisiensi teknis maka petani masih harus menambah atau mengurangi faktor produksi selama proses produksi, sehingga petani melakukan perubahan penggunaan faktor produksinya. Perubahan penggunaan faktor produksi antar petani disesuaikan dengan luas lahan petani.

\section{Efisiensi Alokasi (Harga)}

Efisiensi alokasi merupakan ukuran tingkat keberhasilan petani dalam usaha untuk mencapai keuntungan yang maksimum, Efisiensi harga tercapai pada saat nilai produksi marjinal setiap faktor produksi (MPPxi) sama dengan harga factor produksi tersebut. Dengan kata lain efisiensi harga menunjukkan kemampuan petani untuk menggunakan faktor produksi yang optimal pada masing-masing tingkat harga dan teknologi tertentu.

Petani dikatakan efisien secara alokatif apabila petani mampu menghasilkan output dengan biaya seminimal mungkin dengan menggunakan faktor produksi yang optimal. Proporsi efisiensi alokatif petani karet yang efisien dan inefisien ditunjukkan pada Gambar 2. 


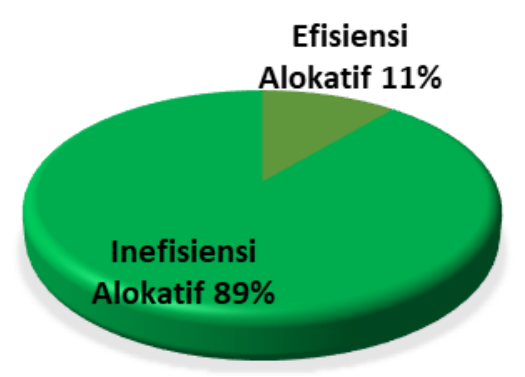

Gambar 2. Proporsi Efisiensi dan Inefisiensi Alokatif Petani Karet di Kecamatan Tapung Hulu Tahun 2018

Berdasarkan Gambar 5.2 dapat dijelaskan bahwa sebanyak 11 persen petani karet efisien secara alokatif dan ada sebanyak 89 persen petani karet yang inefisien. Nilai efisiensi alokatif berkisar antara 0 dan 1 . Nilai efisiensi alokatif yang terkecil sebesar 0.62, yaitu petani sampel ke-28 dan nilai efisiensi alokatif petani yang tertinggi sebesar 1 sebanyak 6 petani, yaitu petani sampel ke 9,21, 22, 24, 36 dan 37. Nilai efisiensi teknis rata-rata petani karet sebesar 0.87 persen.

Hal ini senada dengan hasil penelitian Marjelita, dkk (2015) yang menunjukkan bahwa petani efisien secara teknis belum tentu semua efisien secara alokatif. Dari 60 petani yang diteliti 35 petani $(70 \%)$ yang efisien secara teknis dan 3 orang petani (6\%) yang efisien secara alokatif.

Dengan banyaknya jumlah petani karet yang inefisiensi secara alokatif disebabkan rendahnya kemampuan petani dalam memilih kombinasi faktor produksi yang meminimumkan biaya produksi (minimisasi cost). Dengan kata lain petani belum mampu menyamakan nilai produk marginal dengan harga faktor produksi $(\mathrm{VMPPxi}=$ Pxi). Dengan demikian, petani agar bisa mencapai efisien alokatif dengan cara menggunakan faktor produksi yang optimum dengan biaya yang minimum (minimisasi cost). Meminimum kan biaya dilakukan dengan cara mengkombinasikan penggunaan faktor produksi. Faktor produksi yang harganya mahal harus menggunakan dalam jumlah yang kecil. Sebaliknya faktor produksi yang murah maka petani dapat memakainya dalam jumlah yang banyak.

\section{Efisiensi Ekonomi}

Efisiensi ekonomi merupakan kombinasi antara efisiensi teknis dan efisiensi alokatif. Efisiensi ekonomi tecapai apabila efisiensi teknis dan alokatif tercapai. Efisiensi ekonomi menunjukkan kemampuan petani dalam berproduksi untuk menghasilkan output yang maksimum dengan biaya yang dimilikinya yang menggunakan faktor produksi yang optimal. Efisiensi ekonomi merupakan efisiensi yang paling diinginkan oleh petani. Proporsi efisiensi ekonomi petani karet dan nilai inefisiensi ekonomi dan disajikan pada Gambar 3.

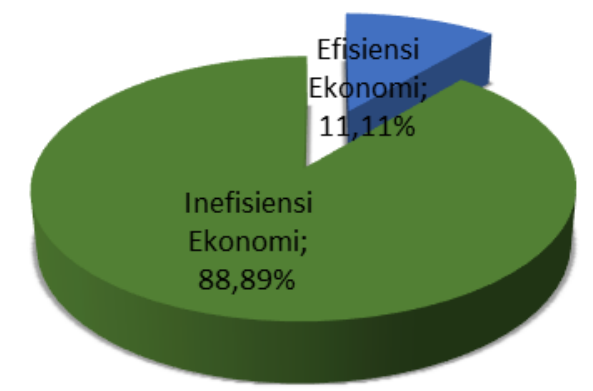

Gambar 3. Proporsi Efisiensi dan Inefisiensi Ekonomi Petani Karet di Kecamatan Tapung Hulu tahun 2018

Berdasarkan Gambar 3. menunjukkan bahwa pada umumnya petani karet belum efisien secara ekonomi. Petani yang mencapai efisien ekonomi sebesar 11.11 persen, sebanyak 6 orang. Sedangkan yang inefisien sebesar 89,89 persen, sebanyak 39 orang.

Nilai efisiensi ekonomi petani berkisar antara 0 dan 1 . Nilai efisiensi ekonomi tertinggi adalah 1 persen dan terendah 0.50 persen. Nilai efisiensi 1 menunjukkan bahwa petani tersebut telah menggunakan faktor produksi yang optimum untuk mendapatkan keuntungan yang maksimum. Nilai efisiensi 1 persen dicapai oleh petani ke- 9, 21,22, 24, 36 dan 37. Nilai efisiensi ekonomi sebesar 0,50 dicapai oleh petani ke-1. Nilai 
efisiensi ekonomi 0,50 menunjukkan bahwa petani belum menggunakan faktor produksi yang optimum untuk mencapai keuntungan yang maksimum, sehingga petani tersebut harus menambah faktor produksi. Petani yang telah mencapai efisiensi ekonomi berarti petani tersebut telah berpeluang untuk memperoleh keuntungan yang maksimum.

\section{Produksi Optimal Dalam Mencapai Faktor Produksi yang Efisiensi}

Petani sebagai produsen dalam berproduksi memiliki tujuan yaitu mencapai keuntungan maksimum. Keuntungan maksimum dicapai dengan menghasil produksi yang optimal. Produksi optimal adalah sejumlah produksi tertentu yang dihasilkan dengan meminimumkan biaya total. Produksi optimal dicapai dengan penggunaan faktor produksi yang efisien secara teknis dan ekonomis. Faktor yang efisien akan menghasilkan keuntungan maksimum. Produksi optimal petani karet dengan menggunakan faktor produksi yang efisien secara teknis disajikan pada Tabel 4.

Tabel 4. Produksi Optimal Petani Karet dengan Penggunaan Faktor Produksi yang Efisiensi Secara Teknis per Luas Garapan Tahun 2018

\begin{tabular}{cccccccc}
\hline Petani & $\begin{array}{c}\text { Produksi } \\
(\mathrm{Kg})\end{array}$ & $\begin{array}{c}\text { Lahan } \\
(\mathrm{Ha})\end{array}$ & $\begin{array}{c}\text { TK } \\
(\mathrm{HOK})\end{array}$ & $\begin{array}{c}\text { Urea } \\
(\mathrm{Kg})\end{array}$ & $\begin{array}{c}\text { KCL } \\
(\mathrm{Kg})\end{array}$ & $\begin{array}{c}\text { TSP } \\
(\mathrm{Kg})\end{array}$ & $\begin{array}{c}\text { Herbisida } \\
(\mathrm{Liter})\end{array}$ \\
\hline 9 & $11.760,00$ & 2,50 & 321,75 & 247,50 & 198,00 & 210,00 & 16,40 \\
5 & $9.000,00$ & 2,00 & 281,00 & 175,00 & 175,00 & 168,00 & 9,76 \\
12 & $9.252,00$ & 2,00 & 258,50 & 188,00 & 141,00 & 168,00 & 13,20 \\
21 & $9.048,00$ & 2,00 & 257,00 & 149,80 & 149,80 & 168,00 & 13,00 \\
42 & $8.436,00$ & 2,00 & 257,00 & 172,40 & 172,40 & 168,00 & 13,20 \\
22 & $7.140,00$ & 1,50 & 165,75 & 133,00 & 99,75 & 126,00 & 8,00 \\
24 & $6.000,00$ & 1,00 & 113,75 & 85,00 & 85,00 & 84,00 & 6,60 \\
36 & $4.920,00$ & 1,00 & 110,00 & 81,00 & 40,50 & 84,00 & 6,60 \\
37 & $2.220,00$ & 0,50 & 56,25 & 42,60 & 42,60 & 42,00 & 3,00 \\
35 & $2.400,00$ & 0,50 & 56,25 & 43,00 & 43,00 & 42,00 & 3,00 \\
\hline
\end{tabular}

Tabel 4 menjelaskan dengan luas lahan yang sama akan menghasilkan produksi optimal yang berbeda dengn penggunaan factor produksi yang berbeda juga. Petani ke 5, 12, 21 dan 42 mengusahakan tanaman karet seluas 2 hektar, namun menghasilkan produksi optimal yang berbeda. Kendatipun demikian, dapat ditarik kesimpulan bahwa dengan luas lahan 2 hektar produksi optimal karet dicapai petani berkisar 8436 $9252 \mathrm{~kg}$ karet basah dengan menggunakan faktor produksi tenaga kerja berkisar antara $257-281 \mathrm{HOK}$, urea berkisar 149,80-188,00 kg, KCL berksar141-175 kg, TSP sebanyak $168 \mathrm{Kg}$ dan penggunaan pestisida berkisar 9,76-13,20.

Petani yang mengusahakan lahan 1 hektar akan menghasil produksi optimal berkisar $4.920-6.000 \mathrm{~kg}$ karet basah dengan penggunaan faktor tenaga kerja berkisar 110,00 - 113,75 HKP, pupuk urea berkisar $81,00-85,00 \mathrm{~kg}$, KCL berkisar 40,50 - 85,00 kg, TSP sebanyak 84,00 $\mathrm{kg}$ dan penggunaan herbisida sebanyak 6,6 liter. Demikian juga petani ke 9 menghasilkan produksi karet lebih banyak dengan penggunaan faktor produksi yang lebih banyak pula.

Selain itu, ada pula petani yang tidak efisien secara teknis dalam mengusahakan usahatani karet sehingga tidak mencapai produksi yang otimal. Berikut petani karet yang tidak efisien di Kecamatan Tapung Hulu yang disajikan pada Tabel 5 .

Tabel 5. Kombinasi Penggunaan Faktor Produksi Petani Karet yang Tidak Efisiensi Tahun 2018

\begin{tabular}{cccccccc}
\hline Petani & Produksi $(\mathrm{Kg})$ & Lahan $(\mathrm{Ha})$ & TK $(\mathrm{HOK})$ & Urea $(\mathrm{Kg})$ & KCL $(\mathrm{Kg})$ & TSP $(\mathrm{Kg})$ & Herbisida (Ltr) \\
\hline 4 & 8400 & 2,00 & 281,13 & 172,00 & 172,00 & 168,00 & 12,00 \\
14 & 9252 & 2,00 & 257,00 & 185,00 & 138,75 & 168,00 & 13,20 \\
18 & 8700 & 2,00 & 240,50 & 184,00 & 138,00 & 168,00 & 13,00 \\
19 & 8640 & 2,00 & 258,50 & 177,00 & 177,0 & 177,00 & 13,20 \\
20 & 9108 & 2,00 & 258,75 & 188,00 & 188,00 & 168,00 & 13,20 \\
31 & 8400 & 2,00 & 255,00 & 172,00 & 129,00 & 168,00 & 13,00 \\
34 & 8580 & 2,00 & 239,00 & 172,80 & 129,60 & 168,00 & 13,20 \\
42 & 8436 & 2,00 & 257,00 & 172,40 & 172,40 & 168,00 & 13,20 \\
45 & 8520 & 2,00 & 254,00 & 173,00 & 172,00 & 168,00 & 10,56 \\
2 & 7080 & 1,5 & 165,81 & 132,00 & 132,00 & 126,00 & 7,52 \\
\hline
\end{tabular}




\begin{tabular}{cccccccc}
\hline Petani & Produksi $(\mathrm{Kg})$ & Lahan $(\mathrm{Ha})$ & TK $(\mathrm{HOK})$ & Urea $(\mathrm{Kg})$ & KCL $(\mathrm{Kg})$ & TSP $(\mathrm{Kg})$ & Herbisida $(\mathrm{Ltr})$ \\
\hline 6 & 7440 & 1,5 & 203,13 & 136,00 & 136,00 & 126,00 & 9,80 \\
7 & 7380 & 1,5 & 179,25 & 137,00 & 137,00 & 126,00 & 9,80 \\
11 & 7320 & 1,5 & 177,75 & 139,00 & 139,00 & 126,00 & 9,80 \\
17 & 7830 & 1,5 & 179,00 & 137,00 & 137,00 & 126,00 & 9,80 \\
26 & 6360 & 1,5 & 162,56 & 133,60 & 100,20 & 126,00 & 9,28 \\
27 & 6600 & 1,5 & 162,38 & 131,00 & 98,25 & 126,00 & 9,80 \\
33 & 6000 & 1,5 & 163,38 & 112,00 & 140,00 & 126,00 & 7,84 \\
39 & 6360 & 1,5 & 165,63 & 135,00 & 94,92 & 126,00 & 9,80 \\
40 & 6240 & 1,5 & 165,75 & 131,00 & 131,00 & 126,00 & 9,80 \\
8 & 5160 & 1,00 & 111,38 & 82,00 & 82,00 & 84,00 & 6,60 \\
15 & 4680 & 1,00 & 112,00 & 88,00 & 88,00 & 84,00 & 6,60 \\
23 & 4800 & 1,00 & 113,50 & 86,00 & 86,00 & 84,00 & 6,60 \\
25 & 5160 & 1,00 & 113,50 & 87,00 & 87,40 & 84,00 & 5,28 \\
28 & 4680 & 1,00 & 110,50 & 79,00 & 98,75 & 84,00 & 6,60 \\
29 & 4500 & 1,00 & 110,25 & 78,00 & 97,50 & 84,00 & 6,60 \\
30 & 4560 & 1,00 & 110,50 & 77,00 & 96,25 & 84,00 & 6,60 \\
32 & 4620 & 1,00 & 109,50 & 78,00 & 97,50 & 84,00 & 6,60 \\
36 & 4920 & 1,00 & 110,00 & 81,00 & 40,50 & 84,00 & 6,60 \\
41 & 4560 & 1,00 & 110,50 & 79,20 & 79,20 & 84,00 & 6,60 \\
\hline
\end{tabular}

Berdasarkan Tabel 5 dapat dijelaskan penggunaan faktor produksi antar petani untuk luas lahan yang sama berbeda-beda, namun untuk penggunaan TSP dan Herbisda hampir sama jumlah penggunaanya. Penggunaan faktor produksi tersebut tidak efisien. Penggunaan faktor produksi yang efisien untuk lahan 2 hektar adalah tenaga kerja ssebanyak 258,50 HOK, pupuk urea sebanyak188 kg, pupuk KCL sebanyak 141 $\mathrm{kg}$, TSP sebanyak168 $\mathrm{kg}$ dan herbsida 13,20 liter dengan produksi optimum $9.252 \mathrm{~kg}$ karet basah. Pada umumnya petani tersebut penggunaan pupuk TSP dan herbisida sudah efisien.

Demikian pula untuk lahan 1,5 hektar. Penggunaaan faktor produksi Tenaga kerja, pupuk urea, KCL, TSP dan herbisida masing-masing 165,75 HOK, $133 \mathrm{~kg}, 99,75 \mathrm{~kg}, 126 \mathrm{~kg}$ dan 8 liter dengan produksi optimum sebanyak $7140 \mathrm{~kg}$ karet basah. Sedangkan untuk lahan 1 hektar, penggunaan faktor produksi Tenaga kerja, pupuk urea, KCL, TSP dan herbisida masing-masing 113,75 HOK, $85 \mathrm{~kg}, 85 \mathrm{~kg}, 84 \mathrm{~kg}$ dan 6,6 liter dengan produksi optimum sebanyak $6.000 \mathrm{~kg}$ karet basah.

Keuntungan maksimum petani karet akan tercapai jika peggunaan faktor produksi efisien secara ekonomi. Efisiesi secara ekonomi tercapai jika penggunaan faktor produksi efisien secata teknis dan alokatif. Penggunaan faktor produksi yang efisien secara ekonomi akan penghasilkan produksi karet yang optimum dan mencapai keuntungan maksimum. Penggunaan faktor produksi karet yang efisies secara ekonomi yang menghasilkan keuntungan maksimum disajikan pada Tabel 6.

Tabel 6. Produksi Optimal Petani Karet Dengan Penggunaan Faktor Produksi yang Efisiensi Secara Ekonomi per Luas Garapan Tahun 2018.

\begin{tabular}{cccccccc}
\hline Petani & $\begin{array}{c}\text { Produksi } \\
(\mathrm{Kg})\end{array}$ & $\begin{array}{c}\text { Lahan } \\
(\mathrm{Ha})\end{array}$ & $\begin{array}{c}\text { TK } \\
(\mathrm{HOK})\end{array}$ & $\begin{array}{c}\text { Urea } \\
(\mathrm{Kg})\end{array}$ & $\begin{array}{c}\text { KCL } \\
(\mathrm{Kg})\end{array}$ & $\begin{array}{c}\text { TSP } \\
(\mathrm{Kg})\end{array}$ & $\begin{array}{c}\text { Herbisida } \\
(\mathrm{Ltr})\end{array}$ \\
\hline 9 & $11.760,00$ & 2,50 & 321,75 & 247,50 & 198,00 & 210,00 & 16,40 \\
21 & $9.048,00$ & 2,00 & 257,00 & 149,80 & 149,80 & 168,00 & 13,00 \\
22 & $7.140,00$ & 1,50 & 165,75 & 133,00 & 99,75 & 126,00 & 8,00 \\
24 & $6.000,00$ & 1,00 & 113,75 & 85,00 & 85,0 & 84,00 & 6,60 \\
37 & $2.220,00$ & 0,50 & 56,25 & 42,60 & 42,60 & 42,00 & 3,00 \\
\hline
\end{tabular}

Tabel 4 dapat dijelaskan produksi optimal dicapai dengan penggunaan faktor produksi yang efisien secara ekonomi. Petani ke 9 pengunaan lahan, tenaga kerja, pupuk urea, KCL, TSP dan pestisida lebih banyak dibandingkan dengan petani lain. Dengan demikian petani 9 akan menghasilkan produksi yang optimal sehingga keuntungan petani tersebut akan maksimal dibandingkan dengan petani lainya. Dengan kata lain penggunaan lahan yang lebih besar akan membutuhkan faktor produksi yang lebih banyak untuk mendapatkan produksi yang optimal. 


\section{KESIMPULAN}

Berdasarkan pemaparan bagian-bagian terdahulu yang telah diuraikan dan mengacu pada tujuan penelitian maka dapat ditarik suatu simpulan, sebagai berikut:

1. Faktor produksi tenaga kerja, pupuk TSP dan herbisida berpengaruhi positif terhadap produksi karet. Elastisitas produksi tenaga kerja, benih dan pupuk urea inelastis.

2. Pada umumnya petani karet belum mencapai efisien secara teknis, alokatif dan ekonomi.

3. Produksi optimal untuk mencapai keuntungan yang maksimal dicapai dengan penggunaan faktor produksi yang efisien secara ekonomi. Penggunaan faktor produksi yang efisien secara ekonomi tercapai jika telah efisien secara teknis dan Alokatif.

\section{UCAPAN TERIMA KASIH}

Puji syukur penulis panjatkan kepada Allah SWT atas berkat rahmatNya bahwa penelitian ini dapat terlaksana sehingga makalah dapat diselesaikan. Selain itu penulis juga mengucapkan terima kasih kepada Lembaga Penelitian dan Pengabdian kepada Masyarakat Universitas Islam Riau yang telah membantu dana untuk terlaksananya penelitian ini.

\section{DAFTAR PUSTAKA}

Agroforestri dan Kehutanan. 2013. Panduan Budidaya Karet untuk Petani Skala Kecil. Lembar Informasi Agriforestry dan Kehutanan. Sulawesi: Agroforestri dan Kehutanan.

Anwar, C. 2001. Budidaya Tanaman Karet. Pusat Penelitian Karet. Medan: MIG Corp.

Coelli, T., D.S.P. Rao., dan G.E. Battese. 1998. An Introduction to Efficiency and Productivity Analysis. London: Kluwer Academic Publisher.

Marjelita, L., F. Restuhadi., dan J. Yusri. 2015. Analisis Efisensi Produksi Petani Padi Peserta Operasi Pangan Riau Makmur (OPRM) di Kabupaten Kampar. Indonesian Journal of Agriculture Economics 6(1): 39-55.

Panjaitan, F.E.D. 2014. Analisis Efisiensi Produksi dan Pendapatan Usahatani Jagung: Studi Kasus Desa Kuala. Kecamatan Tigabinanga, Kabupaten Karo. Medan: Program Studi Agribisis Fakultas Pertanian Universitas Sumatera Utara.

Risandewi, T. 2013. Analisis Efisiensi Produksi Kopi Robusta di Kabupaten Temanggung. Jurnal Litbang Provinsi Jawa Tengah 1(2): 87-201.

Utami, S. 2013. Analisis Efisiensi Produksi Pada Pabrik Pengolahan Kelapa Sawit Gersido Minang Petantation Kecamatan Lingkung Aur Kabupaten Pasaman Barat. http://reposatory unand ac.id/id/eprint/2516 Program Studi Agribisnis, Jurnal. Universitas Andalas.

Wulandari, Elinur, dan S. Vaulina 2014. Analisis Produksi Kelapa Dalam Kabupaten Indragiri Hilir. Jurnal Sistem Agribisnis 6(1): 36-45. 